\title{
Productive performance and digestive response of dairy cows fed different diets combining a total mixed ration and fresh forage
}

\author{
M. Pastorini, ${ }^{1 *}$ N. Pomiés, ${ }^{2 *}$ J. L. Repetto, ${ }^{3}$ A. Mendoza, ${ }^{3,4}$ and C. Cajarville ${ }^{2} \dagger$ \\ ${ }^{1}$ Campo Experimental №2, Facultad de Veterinaria, Universidad de la República, Ruta 1 km 42, CP 80100 San José, Uruguay \\ '2Departamento de Nutrición Animal, Instituto de Producción Animal, Facultad de Veterinaria, Universidad de la República, Ruta 1 km 42, \\ CP 80100 San José, Uruguay \\ ${ }^{3}$ Departamento de Bovinos, Instituto de Producción Animal, Facultad de Veterinaria, Universidad de la República, Ruta 1 km 42 , \\ CP 80100 San José, Uruguay \\ ${ }^{4}$ Programa de Producción de Leche, Instituto Nacional de Investigación Agropecuaria, Ruta 50 km 11, CP 70002 Colonia, Uruguay
}

\section{ABSTRACT}

The purpose of this experiment was to determine the effects of feeding increasing levels of fresh forage $(\mathrm{FF})$ as a proportion of total dry matter intake (DMI) on nutrient intake, rumen digestion, nutrient utilization, and productive performance of total mixed ration (TMR)-fed cows. Twelve dairy cows $(90 \pm 22 \mathrm{~d}$ in milk, $523 \pm 88 \mathrm{~kg}$ of body weight, $7,908 \pm 719 \mathrm{~kg}$ of milk production in the previous lactation) were housed in individual tiestalls and assigned to treatments according to a $3 \times 3$ Latin square design replicated 4 times. Treatments were $100 \%$ TMR (T100), $75 \%$ TMR plus $25 \% \mathrm{FF}$ (T75), and 50\% TMR plus 50\% FF (T50). The experiment lasted $60 \mathrm{~d}$, divided into 3 periods of $20 \mathrm{~d}$ each; the first $12 \mathrm{~d}$ of each period were used for diet adaptation and the last $8 \mathrm{~d}$ for data collection. The TMR (18.1\% crude protein, $24.6 \%$ acid detergent fiber) and FF (Lolium multiflorum; $15.1 \%$ crude protein, $24.1 \%$ acid detergent fiber) were prepared and cut daily and offered to each cow individually. The highest DMI was reached in T100 and T75, which was reflected in greater intake of the different nutrients than T50. No differences were detected in the apparent total digestibility of the nutrients, mean ruminal $\mathrm{pH}$, and total volatile fatty acid concentrations among treatments. Cows in T50 resulted in the lowest ruminal $\mathrm{N}^{-\mathrm{NH}_{3}}$ concentration and the lowest microbial $\mathrm{N}$ flow to the duodenum. Milk yield was $8.5 \%$ higher from cows in T100 and T75 compared with T50, but we observed no differences for milk fat or milk protein yield among treatments. Milk fat of cows fed T50 had $8 \%$ more unsaturated fatty acids (FA) than that of cows fed T100, mostly because of a higher content of monounsaturated FA. Additionally,

Received July 16, 2018.

Accepted January 2, 2019.

*These authors contributed equally to this work.

†Corresponding author: ccajarville@gmail.com cows in T50 had a higher concentration of linoleic acid, vaccenic acid, and rumenic acid than T100. Meanwhile, the concentration of linoleic acid and vaccenic acid in cows fed T75 was higher than T100. The milk fat of the cows fed $\mathrm{T} 50$ and $\mathrm{T} 75$ had a lower $\mathrm{n}-6: \mathrm{n}-3$ ratio than T100. We concluded that including up to $29 \%$ of FF in the total DMI in combination with a TMR did not affect the intake or digestion of nutrients or the productive response in dairy cows and resulted in a higher concentration of desirable FA from a consumer's perspective.

Key words: total mixed ration, pasture, ruminal fermentation, milk production, rumenic acid

\section{INTRODUCTION}

Recently, due to the high costs of TMR-based diets, the utilization of fresh forage $(\mathbf{F F})$ has attracted interest in dairy cow feeding. Additionally, the inclusion of FF in the diet of dairy cows has increased the content of some components with nutraceutical properties (Chaudry, 2008), such as vaccenic and rumenic acids (Elgersma et al., 2006). However, dairy cows exclusively fed FF were not able to reach their maximum productivity potential because of a lower DMI (Kolver, 2003). Lower DMI and energy intake resulted in lower milk yield for cows fed FF than from cows fed TMR (Kolver and Muller, 1998; Bargo et al., 2002a). Those studies indicate that FF diets must be supplemented with energy to guarantee cows can achieve their maximum productive potential. Lower productive performance of animals fed high-quality FF compared with those fed with TMR may be related not only to changes in nutrient ingestion, but also to changes in rumen fermentation and gastrointestinal digestion (Bargo et al., 2002c). One of the alternatives to increase performance of FF-fed cows is to use a TMR as a supplement. This feeding system is called a partially mixed ration (PMR) because FF is not physically part of the TMR (Bargo 
et al., 2002b). Recent studies state that the utilization of PMR could allow cows to attain the DMI and the milk yield achieved by cows fed only TMR (MoralesAlmaráz et al., 2010; Mendoza et al., 2016a); however, when TMR is provided without limitations, the forage is consumed by the cows at very low intake rates and, therefore, represents a low proportion of the final diet. In previous studies using high-producing dairy cows fed a TMR or TMR plus 4 or $8 \mathrm{~h}$ of access to FF, cows fed with TMR and $4 \mathrm{~h}$ of access to FF did not differ in DMI, milk yield, and composition compared with cows fed TMR exclusively (Mendoza et al., 2016a,b), but FF represented only $10.9 \%$ of total DMI. This low FF intake was attributed by the authors to factors related to ingestive behavior (Mendoza et al., 2018). Moreover, those authors observed that cows with up to $8 \mathrm{~h}$ of access to FF ingested no more than $3.6 \mathrm{~kg}$ of DM of FF (16.4\% of the DMI), probably because they preferred the TMR over the forage. Based on previous results, it would be interesting to evaluate the allocation of pasture as a fixed percentage of the diet instead of increasing the time of access to pasture to promote pasture intake.

On the other hand, the ruminal environment of dairy cows consuming high-quality pasture exclusively or pasture plus concentrate is often characterized by low and variable $\mathrm{pH}$ along with high concentrations of $\mathrm{N}_{-} \mathrm{NH}_{3}$ (Van Vuuren et al., 1986; Khalili and Sairanen, 2000). Mendoza et al. (2016b) observed that ruminal environment or nutrient digestion of cows fed TMR with $4 \mathrm{~h}$ of access to FF did not differ from that of cows fed TMR exclusively. Presently, few studies have investigated the effect of diets that combine TMR and FF on nutrient digestion and metabolism and productive performance.

We hypothesized that cows fed a PMR containing $\mathrm{FF}$ up to $25 \%$ can attain a similar DMI and milk yield as cows fed only a TMR, and cows fed this diet will produce milk with a higher content of fatty acids considered beneficial for the health of the consumer. The objective of our experiment was to determine the effects of feeding cows increasing levels of FF as a proportion of total DMI in a TMR on nutrient intake, rumen digestion, nutrient utilization, and productive performance.

\section{MATERIALS AND METHODS}

\section{Animals, Treatments, and Experimental Design}

The experiment was conducted in accordance with regulations governing the use of animals in experimentation, education, and investigation established by the Comisión Honoraria de experimentación Animal of the Universidad de la República (Uruguay; protocol:
PI 12/13 Exp. 111130-000818-13). Twelve Holstein cows (6 fitted with permanent rumen catheters) were selected from the herd of the Experimental Station of Veterinary School (Facultad de Veterinaria, Universidad de la República, Uruguay) in San José, Uruguay $\left(34^{\circ} 40^{\prime} \mathrm{S}, 56^{\circ} 32^{\prime} \mathrm{W}\right)$, with a milk yield record during the previous $305 \mathrm{~d}$ of lactation of $7,908 \mathrm{~kg}(\mathrm{SD}=719)$. At the start of the experiment, on average, cows had a BW of $523 \mathrm{~kg}(\mathrm{SD}=88)$, were at 90 DIM $(\mathrm{DS}=22)$, and had a parity of $3.6(\mathrm{SD}=1.6)$. The experimental design was a $3 \times 3$ Latin square replicated 4 times. Cows were blocked in 4 squares balanced for BW, previous milk yield, DIM, and parity, and within each square they were randomly assigned to treatment sequences. Each period lasted $20 \mathrm{~d}$ and consisted of $12 \mathrm{~d}$ for adaptation followed by $8 \mathrm{~d}$ for data and sample collection. Cows were located in individual tiestalls $(2.0 \times 1.3 \mathrm{~m})$ with meals provided in individual feeders and with free access to water. They were milked twice a day at 0700 and $1800 \mathrm{~h}$. The treatments evaluated were a diet based on TMR exclusively (T100) and 2 mixed diets, one comprising $75 \%$ of the offered DM of TMR plus $25 \%$ FF (T75) and another comprising 50\% of the offered DM of TMR plus 50\% FF (T50). Before the beginning of period 1, the maximum intake achieved by each cow was measured during $7 \mathrm{~d}$ and the total DM offered resulted from the maximum intake achieved plus $20 \%$ to avoid a possible restriction in the DM offered.

The feeding routine began at $0800 \mathrm{~h}$ (hereafter $\mathrm{h} 0$ ). Cows assigned to T100 had ad libitum access to TMR throughout the day. Cows assigned to T50 and T75 had a first TMR session, which represented $30 \%$ of the preplanned total TMR intake that was to be consumed during the day. Once they consumed the total TMR assigned for the session, cows had access to FF. The FF session ended once they completed the total FF intake for each treatment (25 or $50 \%$ of total DM offered). After this, cows had access to a second session of TMR, in which they were offered the remaining $70 \%$ of the preplanned total TMR intake. At $\mathrm{h} 0$ and at every time when the meal was switched, refusals from the feeders were collected and weighed. To guarantee that the amount of meal was not a limiting factor at any time, the feeders were observed every $20 \mathrm{~min}$ and, if necessary, more meal was added.

The pasture used was ryegrass (Lolium multiflorum var. INIA Bakarat), which was seeded on March 15, $2012(15 \mathrm{~kg} / \mathrm{ha})$, fertilized with $27 \mathrm{~kg}$ of N/ha and 69 $\mathrm{kg}$ of $\mathrm{P} / \mathrm{ha}$ with diammonium phosphate, and was used throughout the experimental period. Two months before the beginning of the experiment, the pastureland was divided into 3 paddocks so that forage would be in a vegetative stage throughout the experiment. Each paddock was cut at intervals of 15 to $20 \mathrm{~d}$ and managed 
Table 1. Ingredients and mean nutrient composition $( \pm \mathrm{SD})$ of TMR and fresh forage

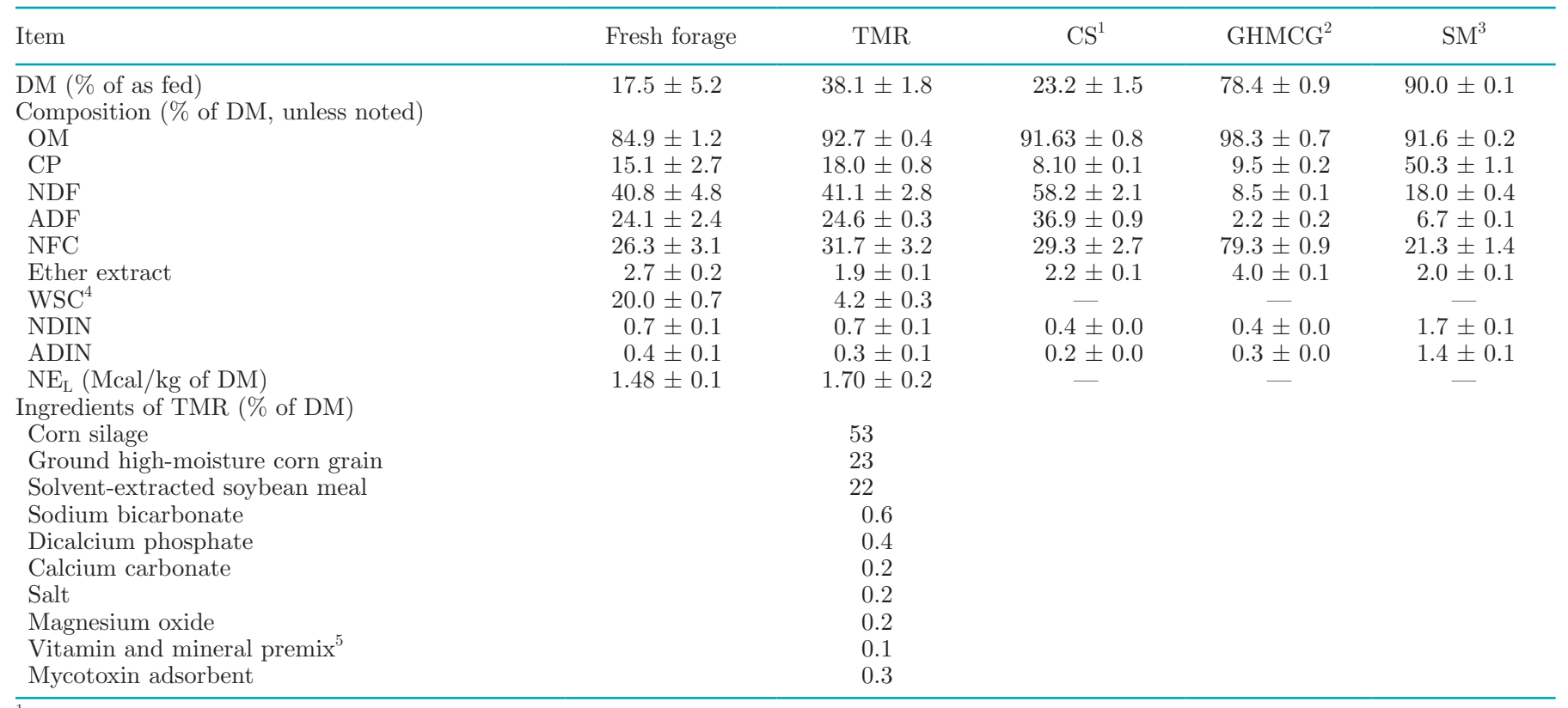

${ }^{1}$ Corn silage.

${ }^{2}$ Ground high-moisture corn grain.

${ }^{3}$ Solvent-extracted soybean meal.

${ }^{4}$ Water-soluble carbohydrates.

${ }^{5}$ Provided (per $\mathrm{kg}$ of $\mathrm{DM}$ ): $0.85 \mathrm{~g}$ of $\mathrm{Cu}, 2.6 \mathrm{~g}$ of $\mathrm{Zn}, 0.9 \mathrm{~g}$ of Se, $1.0 \mathrm{~g}$ of Mn, $23 \mathrm{mg}$ of I, $3 \mathrm{mg}$ of Co, 63,700 IU of vitamin A, 12,700 IU of vitamin $\mathrm{D}$, and $250 \mathrm{IU}$ of vitamin $\mathrm{E}$.

independently of each other, with 1 paddock used during each period. The average forage mass availability of the 3 periods was $2,545 \pm 472 \mathrm{~kg}$ of $\mathrm{DM} / \mathrm{ha}$, with an average height between 20 and $30 \mathrm{~cm}$; all forage used was in a vegetative stage. Forage was harvested daily at $1000 \mathrm{~h}$ with a mower, to a residual height of $10 \mathrm{~cm}$. The FF was immediately collected and stored indoors for a maximum period of $24 \mathrm{~h}$. Nutrient composition of TMR, FF, and the different ingredients used in the TMR are presented in Table 1. Fiber content of the silage was higher than expected because the crop had a low proportion of grain due to drought conditions during the growing season. Because the forage was of medium CP content, the TMR was prepared to ensure that T50 diet would meet the $\mathrm{CP}$ requirements according to NRC (2001).

\section{Feed Analysis}

To consider possible variations in the DM and nutrient composition throughout the day during d 12 to 19 of each period, 3 daily samples were taken of each meal separately (TMR and FF) at 0800, 1400, and $2000 \mathrm{~h}$. A single composite sample was obtained per day by compositing equal parts of these subsamples. Approximately $20 \%$ of feed orts were sampled from each cow.
Every sample was kept frozen at $-20^{\circ} \mathrm{C}$ until analyzed. Feed samples were dried in a forced-air oven at $60^{\circ} \mathrm{C}$ for $48 \mathrm{~h}$ and ground to pass through a 1-mm Wiley mill screen (Arthur H. Thomas Co., Philadelphia, PA). Feed samples were analyzed for DM, ash, total N, and ether extract (AOAC, 1990; methods 934.01, 942.05, 955.04, and 920.39, respectively); NDF using heatstable $\alpha$-amylase and sodium sulfite, ADF, and ADL (Van Soest et al., 1991) expressed exclusive of residual ash; and NDIN and ADIN (Licitra et al., 1996). Organic matter was determined as the difference between DM and ash content. The concentration of NFC was calculated as suggested by NRC (2001) as

$$
\begin{gathered}
\text { NFC }(\%)=100-(\mathrm{NDF} \%+\mathrm{CP} \% \\
+ \text { ether extract } \%+\text { ash } \%) .
\end{gathered}
$$

\section{DM and Nutrient Intake and Digestion in the Digestive Tract}

In each period, daily intake of TMR and FF was measured between $\mathrm{d} 13$ and 20 by weighing the amounts of feed offered and refused. The intake of each fraction of the feed (DM, OM, CP, NDF, and ADF) was determined from the chemical composition. Apparent 
total-tract nutrient digestibility was estimated using the indigestible ADF (iADF) as an internal marker (Huhtanen et al., 1994). On d 13 and 14 of each period, spot fecal samples were collected directly from the rectum from all cows at 0200 and $1400 \mathrm{~h}$, approximately $6 \mathrm{~h}$ before and after the feeding began. Approximately $200 \mathrm{~g}$ of each fecal sample was dried in a forced-air oven at $60^{\circ} \mathrm{C}$ for $72 \mathrm{~h}$ and ground to pass through a 1-mm screen. A composite sample per cow and per period was obtained by mixing equal DM amounts from each sample. A fecal composite sample was analyzed for $\mathrm{DM}$, ash, NDF, ADF, and total N, as previously described. Fecal composite samples, as well as TMR and FF collected as previously described in the Feed Analysis section, were also analyzed for iADF. Briefly, dried samples were ground to pass through a $2-\mathrm{mm}$ screen, and 6 -g samples were weighed into $22-\times 10.5-\mathrm{cm}$ nylon bags (Ankom Technology Corporation, Macedon, NY) with a pore size of $50 \mu \mathrm{m}$ and a sample size-to-surface area ratio of $13 \mathrm{mg} / \mathrm{cm}^{2}$. Samples were incubated for 288 consecutive hours in the rumen of 2 nonlactating Holstein cows fed a diet consisting of (DM basis) $\mathrm{Se}$ taria italica hay (60\%), high-moisture corn grain (25\%), soybean meal $(13 \%)$, and a mineral and vitamin mix $(2 \%)$. Following incubation, bags were rinsed with tap water for $15 \mathrm{~min}$ and dried in a forced-air oven at $60^{\circ} \mathrm{C}$ for $72 \mathrm{~h}$; the residues were analyzed for ADF as previously described. The total fecal output was estimated for each animal by dividing the iADF daily intake by the iADF concentration in feces. Apparent total-tract digestibility (ATD) coefficients for different nutrients (DM, OM, NDF, ADF, and total N) were calculated as

$$
\begin{aligned}
& \operatorname{ATD}=\{[\text { nutrient intake }(\mathrm{g} / \mathrm{d})-\text { fecal nutrient } \\
& \text { output }(\mathrm{g} / \mathrm{d})] / \text { nutrient intake }(\mathrm{g} / \mathrm{d})\} \times 100 .
\end{aligned}
$$

\section{Energy and Nitrogen Balance}

Daily energy balance (EB) was estimated between d 13 and 19 of each period as

$$
\begin{gathered}
\mathrm{EB}\left(\text { Mcal of } \mathrm{NE}_{\mathrm{L}} / \mathrm{d}\right)=\text { energy intake }\left(\mathrm{Mcal} \text { of } \mathrm{NE}_{\mathrm{L}} / \mathrm{d}\right) \\
-\left[\text { maintenance requirements }\left(\mathrm{Mcal} \text { of } \mathrm{NE}_{\mathrm{L}} / \mathrm{d}\right)\right. \\
\left.+ \text { lactation requirements }\left(\text { Mcal of } \mathrm{NE}_{\mathrm{L}} / \mathrm{d}\right)\right] .
\end{gathered}
$$

Energy intake was calculated as $\mathrm{DMI} \times \mathrm{NE}_{\mathrm{L}}$ concentration in feeds. Net energy of lactation concentration was calculated based on the chemical composition of feed analysis according to NRC (2001). The maintenance requirements were calculated as $0.08 \times \mathrm{BW}^{0.75}(\mathrm{NRC}$, 2001). Body weight was measured with a digital scale at the beginning of the experiment and at the end of each period, and the average for each period was used for the energy balance calculations. The requirement for lactation (RL) was calculated as suggested by NRC (2001) using the following equation:

$$
\begin{gathered}
\mathrm{RL}\left(\text { Mcal of } \mathrm{NE}_{\mathrm{L}} / \mathrm{d}\right)=\text { milk yield } \times(0.0929 \times \text { fat } \% \\
+0.0547 \times \mathrm{CP} \%+0.0395 \times \text { lactose } \%) .
\end{gathered}
$$

Average milk composition for each period was used to calculate requirement for lactation. Requirements for pregnancy, growth, and grazing were not considered because the cows were not gestating, they were in at least their third lactation, and because FF was offered in feeders and the cows did not actually graze.

Daily N balance (NB) was calculated during d 13 and 14 of each period as

$$
\begin{gathered}
\mathrm{NB}(\mathrm{g} / \mathrm{d})=\mathrm{N} \text { intake }(\mathrm{g} / \mathrm{d})-[\text { fecal } \mathrm{N} \text { output }(\mathrm{g} / \mathrm{d}) \\
+ \text { urine } \mathrm{N} \text { output }(\mathrm{g} / \mathrm{d})+\text { milk } \mathrm{N} \text { output }(\mathrm{g} / \mathrm{d})] .
\end{gathered}
$$

Daily total volume of urine was indirectly estimated by creatinine quantification in urine, as is later described for microbial $\mathrm{N}$ utilization, using the method defined by Valadares et al. (1999). Daily total fecal excretion was indirectly estimated using iADF as an internal marker (Huhtanen et al., 1994), as previously described for digestibility. The concentration of urine $\mathrm{N}$ and fecal $\mathrm{N}$ was determined using the Kjeldahl method (AOAC, 1990; method 955.04). Nitrogen in manure was calculated as $\mathrm{N}$ urine plus $\mathrm{N}$ fecal. For the determination of milk $\mathrm{N}$ secretion, milk samples were taken as described for determination of milk composition, and daily milk $\mathrm{N}$ secretion was calculated as milk protein $(\mathrm{g} / \mathrm{d})$ divided by 6.38 (NRC, 2001).

\section{Rumen Fermentation}

On d 20 of each period, samples of ruminal fluid were taken every hour for 12 consecutive hour (h 0 , $1,2,3,4,5,6,7,8,9,10,11$, and 12 ; h $0=0800 \mathrm{~h}$ ). Ruminal fluid $\mathrm{pH}$ was immediately measured using a digital pH meter (EW-05991-36, Cole Parmer, Vernon Hills, IL). Ruminal liquid was pressed through 2 layers of cheesecloth, and a 10-mL sample of ruminal fluid was preserved with $0.2 \mathrm{~mL}$ of $6.6 \mathrm{M} \mathrm{H}_{2} \mathrm{SO}_{4}$ for $\mathrm{NH}_{3} \mathrm{~N}$ analysis. Another 0.5-mL sample was preserved with $0.5 \mathrm{~mL}$ of $0.1 \mathrm{M} \mathrm{HClO}_{4}$ for VFA analysis. Both samples were stored at $-20^{\circ} \mathrm{C}$ until analysis.

For $\mathrm{NH}_{3}-\mathrm{N}$ determination, samples were thawed at room temperature and analyzed by direct distillation using sodium tetraborate and titration with $0.05 \mathrm{M}$ $\mathrm{HCl}$ (Aguerre et al., 2013). For VFA determination, 
only samples taken at h $0,3,6,9$, and 12 were analyzed. Samples were thawed at room temperature, centrifuged $\left(10,000 \times g\right.$ at $4^{\circ} \mathrm{C}$ for $\left.15 \mathrm{~min}\right)$, and analyzed using HPLC (Dionex Ultimate 3000, Sunnyvale, CA), as described by Adams et al. (1984), using an Acclaim Rezex Organic Acid $\mathrm{H}^{+}$column (8\%; Phenomenex, Torrance, $\mathrm{CA}$ ) of $7.8 \times 300 \mathrm{~mm}$, adjusted at $210 \mathrm{~nm}$. Concentrations of acetic, propionic, and butyric acid were reported in concentration units and as molar proportions; total VFA concentration was calculated as the sum of acetic, propionic, and butyric acid concentrations.

\section{Microbial N Flow and N Utilization}

On d 13 and 14 of each period, the microbial $\mathrm{N}$ flow was indirectly estimated through creatinine concentration and urine purine derivative quantification according to Valadares et al. (1999). Two urine spot samples of $15 \mathrm{~mL}$ each were collected from all cows at 0200 and $1400 \mathrm{~h}$ (approximately $6 \mathrm{~h}$ before and after the beginning of the feeding bout), which were acidified with $60 \mathrm{~mL}$ of $0.072 \mathrm{~N} \mathrm{H}_{2} \mathrm{SO}_{4}$ and stored at $-20^{\circ} \mathrm{C}$ until posterior analysis (Broderick et al., 2009). Urine samples were later thawed at room temperature, and equal parts of each of the 4 samples were mixed to obtain a composite sample, which was used for analyses. Urine samples were analyzed for creatinine with a colorimetric method utilizing a commercial kit (Wiener Laboratories S.A.I.C. 2000, Rosario, Argentina). The minimum detectable concentration was $0.09 \mathrm{mg} / \mathrm{L}$. The intra-assay coefficients of variation for low (10 $\mathrm{mg} / \mathrm{L})$ and high control $(40 \mathrm{mg} / \mathrm{L})$ were 4.7 and $0.9 \%$, respectively. Duplicate samples were analyzed utilizing a spectrophotometer (1200, UNICO; United Products \& Instruments Inc., Dayton, $\mathrm{OH})$. The concentrations of uric acid and allantoin in urine were analyzed as described by Balcells et al. (1992) using HPLC (Dionex Ultimate 3000), using an Acclaim C18 (Phenomenex) column of $205 \mathrm{~nm}, 5 \mu \mathrm{m}, 4.6 \times 250 \mathrm{~mm}$. The daily total excretion of purine derivatives $(\mathbf{P D} ; \mathrm{mmol} / \mathrm{d})$ was calculated as the ratio of the concentration $(\mathrm{mmol} / \mathrm{L})$ of $\mathrm{PD}$ to creatinine in the spot sample times the expected creatinine excretion $(\mathrm{mmol} / \mathrm{d})$, which was estimated assuming a daily creatinine excretion rate of $29 \mathrm{mg} /$ $\mathrm{kg}$ of BW (Valadares et al., 1999). Flow of microbial N (FMN) to duodenum was estimated according Chen and Gomes (1992), except for the 0.134 factor that was taken from Valadares et al. (1999):

$$
\operatorname{FMN}(\mathrm{g} / \mathrm{d})=(\mathrm{PA} \times 70) /(0.134 \times 0.83 \times 1,000),
$$

where PA is the purines absorption $(\mathrm{mmol} / \mathrm{d}), 70$ is the $\mathrm{N}$ content of the purines ( $\mathrm{mg}$ of $\mathrm{N} / \mathrm{mmol}$ ), 0.134 is the relation between $\mathrm{N}$ of the purines/total $\mathrm{N}$, and 0.83 is the assumed digestibility of the microbial origin purines. Efficiency of $\mathrm{N}$ use for microbial $\mathrm{N}$ synthesis (EUMN) was calculated as

$$
\begin{gathered}
\text { EUMN }(\%)=[\text { microbial } N \text { flow }(\mathrm{g} / \mathrm{d}) / \\
\text { total } \mathrm{N} \text { intake }(\mathrm{g} / \mathrm{d})] \times 100 .
\end{gathered}
$$

Efficiency of utilization of feed $\mathrm{N}$ for milk production (EUMP) was calculated as

$$
\begin{gathered}
\operatorname{EUMP}(\%)=[\text { milk N output }(\mathrm{g} / \mathrm{d}) / \\
\mathrm{N} \text { intake }(\mathrm{g} / \mathrm{d})] \times 100 .
\end{gathered}
$$

Milk N secretion and urine was calculated as previously described.

\section{Milk Production and Composition}

Milk production was recorded from d 13 to 18 during each period for the 2 milkings. Individual milk samples were collected in 4 consecutive milkings at d 15 and 16 of each period, using bronopol as preservative agent; the samples were used to determine fat, protein, total casein, lactose, and MUN by infrared analysis (model 2000, Bentley Instruments Inc., Chaska, MN). Yield of $3.5 \%$ FCM was calculated according to Tyrrell and Reid (1965).

Two additional individual milk samples were taken without preservatives on $\mathrm{d} 15$ from each milking and stored at $-20^{\circ} \mathrm{C}$ until analyzed for fatty acid composition. For FA analysis, frozen milk samples were thawed at room temperature and milk lipids were separated according to Feng et al. (2004). A 50-mg aliquot of milk fat was dissolved in $100 \mu \mathrm{L}$ of hexane, followed by esterification with $100 \mu \mathrm{L}$ of $2 N$ potassium hydroxide in methanol to obtain the FAME, which were separated and quantified using a GC-MS (Agilent 7890A GC System, Agilent Technologies Inc., Santa Clara, CA) equipped with a $60-\mathrm{m}$ column $(250-\mu \mathrm{m}$ i.d., $0.25-\mu \mathrm{m}$ film thickness; Thermo Scientific Inc., Marietta, $\mathrm{OH}$ ). Helium was used as the carrier gas, with a flow rate of $1.0 \mathrm{~mL} / \mathrm{min}$. The injector temperature (split ratio of 100:1) was set to $250^{\circ} \mathrm{C}$. The initial column temperature $\left(40^{\circ} \mathrm{C}\right)$ was held for $0.5 \mathrm{~min}$, increased at $25^{\circ} \mathrm{C} /$ min to $175^{\circ} \mathrm{C}$ and held for $10 \mathrm{~min}$, then increased at a $5^{\circ} \mathrm{C} / \mathrm{min}$ to $210^{\circ} \mathrm{C}$ and held for $5 \mathrm{~min}$. Finally, column temperature was increased at a rate of $5^{\circ} \mathrm{C}$ per min to $230^{\circ} \mathrm{C}$ and held for $5 \mathrm{~min}$.

Fatty acids were identified by comparing their retention times with the following FAME standards: 37 components FAME mix (47885, Supelco, Bellefonte, PA), 
trans-11-octadienoic methyl ester (46905-U, Supelco), octadecadienoic acid conjugated methyl ester (05632, Sigma-Aldrich, St. Louis, MO), and those stored in the National Institute of Standards and Technology (Gaithersburg, MD). The $\Delta^{9}$-desaturase index and the atherogenicity index were calculated as described by Kelsey et al. (2003) and Ulbricht and Southgate (1991), respectively.

\section{Statistical Analysis}

All data were analyzed using SAS software version 9.0 (SAS Institute Inc., Cary, NC). Data were initially submitted for analysis to detect outliers and to check the normality of the residuals through univariate procedures (PROC UNIVARIATE).

Data of intake, milk yield and composition, FA profile, $\mathrm{N}$ balance, microbial $\mathrm{N}$ flow, and milk yield efficiencies were analyzed using the PROC MIXED procedure with the following model:

$$
\mathrm{Y}_{\mathrm{ijkl}}=\mu+\mathrm{S}_{\mathrm{i}}+\mathrm{C}_{\mathrm{j}}\left(\mathrm{S}_{\mathrm{i}}\right)+\mathrm{P}_{\mathrm{k}}+\mathrm{T}_{1}+\mathrm{e}_{\mathrm{ijkl}},
$$

where $Y_{\mathrm{ijkl}}$ is the dependent variable, $\mu$ is the overall mean, $\mathrm{S}_{\mathrm{i}}$ is the random effect of the square $(\mathrm{i}=1$ to 4), $\mathrm{C}_{\mathrm{j}}\left(\mathrm{S}_{\mathrm{i}}\right)$ is the random effect of cows nested within the square $(\mathrm{j}=1$ to 4$), \mathrm{P}_{\mathrm{k}}$ is the random effect of period $(\mathrm{k}$ $=1$ to 3$), \mathrm{T}_{1}$ is the fixed effect of treatment $(\mathrm{l}=\mathrm{T} 100$, $\mathrm{T} 75$, or $\mathrm{T} 50)$, and $\mathrm{e}_{\mathrm{ijkl}}$ is the residual error.

The data of the variables with repeated measurements over time in each period, such as rumen $\mathrm{pH}$, $\mathrm{N}-\mathrm{NH}_{3}$, and VFA, were analyzed using PROC MIXED procedure with the following model:

$$
\begin{aligned}
\mathrm{Y}_{\mathrm{ijklm}}=\mu & +\mathrm{S}_{\mathrm{i}}+\mathrm{C}_{\mathrm{j}}\left(\mathrm{S}_{\mathrm{i}}\right)+\mathrm{P}_{\mathrm{k}}+\mathrm{T}_{1}+\mathrm{H}_{\mathrm{m}} \\
& +\mathrm{T}_{1} \times \mathrm{H}_{\mathrm{m}}+\mathrm{e}_{\mathrm{ijklm}},
\end{aligned}
$$

where $Y_{\mathrm{ijklm}}$ is the dependent variable, $\mu$ is the overall mean, $\mathrm{S}_{\mathrm{i}}$ is the random effect of the square ( $\mathrm{i}=1$ to 4 ), $\mathrm{C}_{\mathrm{j}}\left(\mathrm{S}_{\mathrm{i}}\right)$ is the random effect of cows nested in the square $(\mathrm{j}=1$ to 4$), \mathrm{P}_{\mathrm{k}}$ is the random effect of period ( $\mathrm{k}=1$ to $3), T_{1}$ is the fixed effect of treatment $(1=\mathrm{T} 100$, T75, or T50), $\mathrm{H}_{\mathrm{m}}$ is the fixed effect of the hour of measurement, $\mathrm{T}_{1} \times \mathrm{H}_{\mathrm{m}}$ is the fixed effect of the interaction between treatment and hour of measurement, and $\mathrm{e}_{\mathrm{ijk} k \mathrm{~m}}$ is the residual error. The period $\times$ cow interaction within a square was the subject of repeated measurements, and $\mathrm{AR}(1)$ was the covariance structure chosen (Littell et al., 1998). A treatment $\times$ period effect was tested in both models, but it was not significant and was therefore removed. Means were compared with the Tukey test. Significant differences were declared at $P \leq 0.05$, and trends were discussed at $0.05<P \leq 0.10$.

\section{RESULTS AND DISCUSSION}

\section{DM and Nutrient Intake and Digestion in the Digestive Tract}

The actual percentages of TMR and FF were 71 and $29 \%$ in T75 and 53 and $47 \%$ in T50, respectively, which were very similar to the values set as targets in the experimental design (Table 2). No differences were observed in total DMI or nutrients between T100 and T75, which implies that the inclusion of up to $29 \%$ of $\mathrm{FF}$ in the diet did not affect voluntary DMI. However, DMI in T50 was 8.1 and $7.5 \%$ lower than T100 and T75, respectively, and the same tendency was observed for the intake of other nutrients. Previous studies reported that DMI decreases as the amount of FF increases in the diet of TMR-fed dairy cows (Vibart et al., 2008). However, and similar to what happened in this experiment, if a high-quality forage is used, up to approximately $30 \%$ of $\mathrm{FF}$ inclusion in the diet does not affect the DMI, allowing the cows to achieve a similar total DMI compared with cows fed only with TMR (Vibart et al., 2008; Morales-Almaráz et al., 2010).

Apparent total-tract nutrient digestibility was not affected by the treatments. Other authors also observed no differences among treatments in DM and nutrient digestibility between dairy cows consuming a $100 \%$ TMR diet and diets that combined TMR with highquality FF (Bargo et al., 2002b; Mendoza et al., 2016b). However, Bargo et al. (2002b) observed that the NDF digestibility was lower for cows fed 100\% TMR diets than for cows fed PMR or pasture plus concentrate.

\section{Energy and Nitrogen Balance}

The energy intake and the milk energy output were 13.5 and $9.8 \%$ lower in T50 than T100, respectively, consistent with the positive but lower EB in T50 than in T100 (Table 3). Bargo et al. (2002b) and Mendoza et al. (2016b) also reported a higher milk energy output associated with a higher energy intake.

The $\mathrm{N}$ intake was $12.6 \%$ higher for cows in T100 and T75 than for cows in T50 (Table 3) and was consistent with differences observed in total DMI and CP content among treatments. Urine $\mathrm{N}$ excretion was higher for cows in T100 than in T75, which in turn was higher than T50 (Table 3). This could be explained by the relative $\mathrm{N}$ and RDP intakes in the different treatments, and agrees with previous studies (Castillo et al., 2000; Colmenero and Broderick, 2006) that reported that N excreted in urine is linearly related to $\mathrm{N}$ intake due to higher amounts of $\mathrm{NH}_{3}$ absorbed into the blood, converted to urea in the liver, and excreted in the urine. Fecal $\mathrm{N}$ excretion was not affected by the treatments 
Table 2. Intake and digestibility of nutrients of dairy cows fed different proportions of TMR and fresh forage

\begin{tabular}{lccccc}
\hline & \multicolumn{3}{c}{ Treatment $^{1}$} & & \\
\cline { 2 - 3 } Item & T100 & T75 & T50 & SEM & $P$-value \\
\hline DMI (kg/d, unless noted) & & & & & \\
TMR & $24.8^{\mathrm{a}}$ & $17.6^{\mathrm{b}}$ & $12.1^{\mathrm{c}}$ & 0.84 & $<0.001$ \\
Fresh forage & 0.0 & $7.0^{\mathrm{a}}$ & $10.7^{\mathrm{b}}$ & 0.29 & $<0.001$ \\
Total & $24.8^{\mathrm{a}}$ & $24.6^{\mathrm{a}}$ & $22.8^{\mathrm{b}}$ & 0.94 & 0.018 \\
Total (\% of BW) & $4.3^{\mathrm{a}}$ & $4.3^{\mathrm{ab}}$ & $4.0^{\mathrm{b}}$ & 0.17 & 0.029 \\
TMR in total DM (\%) & $100.0^{\mathrm{a}}$ & $71.3^{\mathrm{b}}$ & $52.9^{\mathrm{c}}$ & 1.11 & $<0.001$ \\
Fresh forage in total DM (\%) & $0.0^{\mathrm{a}}$ & $28.7^{\mathrm{b}}$ & $47.1^{\mathrm{c}}$ & 1.11 & $<0.001$ \\
Nutrient intake (kg/d) & & & & & \\
OM & $23.0^{\mathrm{a}}$ & $22.4^{\mathrm{a}}$ & $20.4^{\mathrm{b}}$ & 0.78 & 0.001 \\
NDF & $10.2^{\mathrm{a}}$ & $10.1^{\mathrm{ab}}$ & $9.4^{\mathrm{b}}$ & 1.81 & 0.030 \\
ADF & $6.1^{\mathrm{a}}$ & $6.0^{\mathrm{ab}}$ & $5.6^{\mathrm{b}}$ & 0.31 & 0.024 \\
NFC & $7.9^{\mathrm{a}}$ & $7.4^{\mathrm{a}}$ & $6.7^{\mathrm{b}}$ & 0.28 & $<0.001$ \\
Digestibility (\%) & & & & & \\
DM & 66.0 & 66.3 & 66.4 & 0.42 & 0.778 \\
OM & 65.6 & 66.3 & 66.7 & 0.53 & 0.354 \\
CP & 67.8 & 67.6 & 65.9 & 1.72 & 0.134 \\
NDF & 60.7 & 59.7 & 59.2 & 0.90 & 0.246 \\
ADF & 56.7 & 56.7 & 54.5 & 3.64 & 0.441 \\
\hline
\end{tabular}

${ }^{\mathrm{a}-\mathrm{c}}$ Within a row, the means with different superscripts are different $(P \leq 0.05)$.

${ }^{1} \mathrm{~T} 100=100 \% \mathrm{TMR} ; \mathrm{T} 75=75 \%$ TMR plus $25 \%$ fresh forage; T50 $=50 \%$ TMR plus $50 \%$ fresh forage.

(Table 3). According to Van Soest (1994), fecal N excretion is rather constant as a proportion to total DMI, representing about $0.6 \%$, which is consistent with the data of the present experiment. Although the DMI was lower for cows in T50 than T100 and T75, it seems that this difference was not enough to detect differences in fecal N excretion. Furthermore, according to Castillo et al. (2000), when $\mathrm{N}$ intake is greater than $400 \mathrm{~g} / \mathrm{d}$,

Table 3. Energy and N balance of dairy cows fed different proportions of TMR and fresh forage

\begin{tabular}{|c|c|c|c|c|c|}
\hline \multirow[b]{2}{*}{ Item } & \multicolumn{3}{|c|}{ Treatment $^{1}$} & \multirow[b]{2}{*}{ SEM } & \multirow[b]{2}{*}{$P$-value } \\
\hline & $\mathrm{T} 100$ & T75 & T50 & & \\
\hline \multicolumn{6}{|l|}{$\mathrm{NE}_{\mathrm{L}}$ intake $(\mathrm{Mcal} / \mathrm{d})$} \\
\hline TMR & $42.2^{\mathrm{a}}$ & $29.9^{\mathrm{b}}$ & $20.6^{\mathrm{c}}$ & 1.41 & $<0.001$ \\
\hline Fresh forage & $0.0^{\mathrm{a}}$ & $10.3^{\mathrm{b}}$ & $15.9^{\mathrm{c}}$ & 0.56 & $<0.001$ \\
\hline Total & $42.2^{\mathrm{a}}$ & $40.2^{\mathrm{a}}$ & $36.5^{\mathrm{b}}$ & 1.56 & $<0.001$ \\
\hline Milk $\mathrm{NE}_{\mathrm{L}}$ yield (Mcal/d) & $23.1^{\mathrm{a}}$ & $22.8^{\mathrm{a}}$ & $20.9^{\mathrm{b}}$ & 0.91 & 0.001 \\
\hline $\mathrm{NE}_{\mathrm{L}}$ balance $(\mathrm{Mcal} / \mathrm{d})$ & $8.9^{\mathrm{a}}$ & $7.2^{\mathrm{ab}}$ & $5.4^{\mathrm{b}}$ & 1.27 & 0.008 \\
\hline \multicolumn{6}{|l|}{$\mathrm{N}$ intake $(\mathrm{g} / \mathrm{d})$} \\
\hline TMR & $715.4^{\mathrm{a}}$ & $504.1^{\mathrm{b}}$ & $346.1^{\mathrm{c}}$ & 23.62 & $<0.001$ \\
\hline Fresh forage & $0.0^{\mathrm{a}}$ & $169.1^{\mathrm{b}}$ & $260.5^{\mathrm{c}}$ & 7.08 & $<0.001$ \\
\hline Total & $715.4^{\mathrm{a}}$ & $673.2^{\mathrm{a}}$ & $606.6^{\mathrm{b}}$ & 26.18 & $<0.001$ \\
\hline \multicolumn{6}{|l|}{ Urinary $\mathrm{N}$ excretion } \\
\hline $\mathrm{g} / \mathrm{d}$ & $335.7^{\mathrm{a}}$ & $309.3^{\mathrm{b}}$ & $279.8^{\mathrm{c}}$ & 13.71 & $<0.001$ \\
\hline$\%$ of $\mathrm{N}$ intake & 47.2 & 46.5 & 46.0 & 1.51 & 0.771 \\
\hline \multicolumn{6}{|l|}{ Fecal N excretion } \\
\hline $\mathrm{g} / \mathrm{d}$ & 144.5 & 137.5 & 134.5 & 7.16 & 0.276 \\
\hline$\%$ of $\mathrm{N}$ intake & 20.2 & 20.4 & 22.3 & 1.58 & 0.174 \\
\hline \multicolumn{6}{|l|}{ Manure N excretion } \\
\hline $\mathrm{g} / \mathrm{d}$ & $480.1^{\mathrm{a}}$ & $446.7^{\mathrm{b}}$ & $414.2^{\mathrm{c}}$ & 13.23 & $<0.001$ \\
\hline$\%$ of $\mathrm{N}$ intake & 67.4 & 66.8 & 68.3 & 2.43 & 0.819 \\
\hline \multicolumn{6}{|l|}{ Milk N excretion } \\
\hline $\mathrm{g} / \mathrm{d}$ & $161.7^{\mathrm{a}}$ & $159.6^{\mathrm{a}}$ & $148.2^{\mathrm{b}}$ & 6.1 & 0.004 \\
\hline$\%$ of $\mathrm{N}$ intake & $22.7^{\mathrm{x}}$ & $23.9^{\mathrm{xy}}$ & $24.5^{\mathrm{y}}$ & 0.72 & 0.069 \\
\hline \multicolumn{6}{|l|}{$\mathrm{N}$ balance } \\
\hline $\mathrm{g} / \mathrm{d}$ & $73.6^{\mathrm{a}}$ & $66.9^{\mathrm{a}}$ & $44.2^{\mathrm{b}}$ & 8.26 & 0.009 \\
\hline$\%$ of $\mathrm{N}$ intake & 9.9 & 9.3 & 7.2 & 1.91 & 0.428 \\
\hline
\end{tabular}

${ }^{\mathrm{a}-\mathrm{c}}$ Within a row, the means with different superscripts are different $(P<0.05)$.

${ }^{\mathrm{x}, \mathrm{y}}$ Within a row, the means with different superscripts are different $(0.05<P<0.10)$.

${ }^{1} \mathrm{~T} 100=100 \% \mathrm{TMR} ; \mathrm{T} 75=75 \%$ TMR plus $25 \%$ fresh forage; $\mathrm{T} 50=50 \%$ TMR plus $50 \%$ fresh forage. 
the proportion of $\mathrm{N}$ excreted in urine increases exponentially, whereas $\mathrm{N}$ output in feces and milk declines linearly. In our experiment, urine $\mathrm{N}$ represented 52.3, 51.0, and $49.8 \%$ and fecal and milk $\mathrm{N}$ represented 47.7, 49.0 , and $50.2 \%$ of total $\mathrm{N}$ excreted for T100, T75, and T50, respectively. Total manure $\mathrm{N}$ excretion followed a similar pattern as urine $\mathrm{N}$ excretion. Expressed as a percentage of $\mathrm{N}$ intake, the average manure $\mathrm{N}$ excretion was $67.5 \%$ and was not affected by the treatments, which is very similar to the $72 \%$ reported by Castillo et al. (2000) for dairy cattle.

The milk $\mathrm{N}$ output was on average, $8 \%$ higher in both T100 and T75 compared with T50 (Table 3). Likewise, we observed that T50 cows tended to have a greater efficiency of utilization of feed $\mathrm{N}$ for milk production than T100 cows. This result is consistent with reports from other authors (Castillo et al., 2000; Colmenero and Broderick, 2006), who affirmed that as dietary N intake increased, the efficiency of $\mathrm{N}$ utilization for milk production linearly decreased. Last, $\mathrm{N}$ balance was positive in the 3 treatments, but it was $37 \%$ higher in cows fed T100 and T75 compared with cows fed T50, consistent with the $\mathrm{N}$ intake.

\section{Rumen Fermentation}

Although no differences among treatments were observed in mean ruminal $\mathrm{pH}$ (Table 4), the minimum $\mathrm{pH}$ of cows in T75 and T50 was lower than cows in T100, although the range was greater in cows fed a PMR diet compared with those consuming TMR exclusively. Likewise, an interaction between treatment and hour was observed for the average $\mathrm{pH}$ values. Cows in T100 had a more stable daily $\mathrm{pH}$ dynamic and remained above a $\mathrm{pH}$ of 6 throughout the day (Figure 1). This value has been proposed as the minimum $\mathrm{pH}$ needed to optimize OM digestion and microbial protein synthesis (Calsamiglia et al., 2008). No interaction between treatment and hour was detected for total and individual VFA concentrations or relative proportions. Total and individual VFA concentrations were not affected by treatments (Table 4), presumably because the higher OM intake of cows in T100 and T75 did not result in a higher quantity of fermentable substrates compared with cows in T50. This result agrees with those reported by Bargo et al. (2002c), who did not observe differences in VFA concentrations between animals fed TMR and TMR + pasture diets. The inclusion of FF altered the molar proportions of propionic and butyric acid. The propionic acid proportion was higher for cows in T100 than cows in T75 and T50, whereas the acetic-to-propionic and acetic + butyric-to-propionic ratio was lower for cows in T100 than cows in T75 and T50 (Table 4). These results are consistent with the higher intake of
NFC by cows in T100, because diets rich in NFC favor a higher propionate rumen production (France and Dijkstra, 2005). The butyric acid proportion was lower for cows in T100 than cows in T75 and T50, which is in line with results reported by Mendoza et al. (2016b), who attributed this fact to a higher intake of soluble sugars contained in the FF.

Even though the average ruminal concentration of $\mathrm{N}-\mathrm{NH}_{3}$ was consistently above the minimum values needed to optimize the rumen microbial growth $(8 \mathrm{mg} /$ dL; Clark et al., 1992; Reynal and Broderick, 2005), the average concentration was lower for cows in T50 than cows in T75 and T100 (Table 4) due to the lower N intake observed for cows in T50. In addition, it is probable that the TMR had a higher RDP concentration than desired, a fact consistent with the NDIN percentage observed in the soybean meal used $(1.7 \pm 0.1 \%)$, which was much lower than expected for this supplement according to Sniffen et al. (1992). Mendoza et al. (2016b) also observed higher ruminal concentrations of $\mathrm{N}-\mathrm{NH}_{3}$ in animals fed a TMR diet exclusively compared with animals fed with a TMR and 4 or $8 \mathrm{~h}$ of access to FF, which was, as in the present study, Lolium multiflorum with high digestibility but a relatively low $\mathrm{CP}$ content (17\%). Meanwhile, Bargo et al. (2002c), using a mixture of Bromus inermis, Dactylis glomerata, and Poa pratensis with a high CP content (26\%), observed the highest rumen concentrations of $\mathrm{N}^{-\mathrm{NH}_{3}}$ in animals fed pasture plus concentrate than those fed TMR plus pasture or TMR exclusively, a result those authors explained due to a higher intake of soluble $\mathrm{CP}$ from the pasture. In our study, no interaction between treatment and hour was detected for this trait, with maximum concentrations from h $0(23.7 \mathrm{mg} / \mathrm{dL})$ to 2 postfeeding, which began to decrease from $\mathrm{h} 3$ until reaching the minimum concentration at h $6(14.9 \mathrm{mg} / \mathrm{dL})$. From h 6 on, $\mathrm{N}_{-} \mathrm{NH}_{3}$ began to increase until reaching a concentration of $18.1 \mathrm{mg} / \mathrm{dL}$ at $\mathrm{h} 12$ (Figure 1). These rumen $\mathrm{N}-\mathrm{NH}_{3}$ concentration dynamics are consistent with the observed $\mathrm{pH}$ value changes throughout the day and might be related to differences in the intake rate of both TMR and FF throughout the day.

\section{Microbial N Flow and N Utilization}

Urinary concentrations of creatinine, allantoin, and uric acid and the urinary excretion of PD were not affected by the treatments, but the total PD excretion $(\mathrm{mmol} / \mathrm{d})$ and the duodenum FMN were higher for cows in T100 and T75 than cows in T50 (Table 5). This is consistent with the higher DM, N, and energy intake observed for cows in T100 and T75 than cows in T50. Conversely, neither Mendoza et al. (2016b) nor Bargo et al. (2002b) observed differences between treat- 
Table 4. Ruminal pH, VFA, and ammonia-N concentrations of dairy cows fed different proportions of TMR and fresh forage

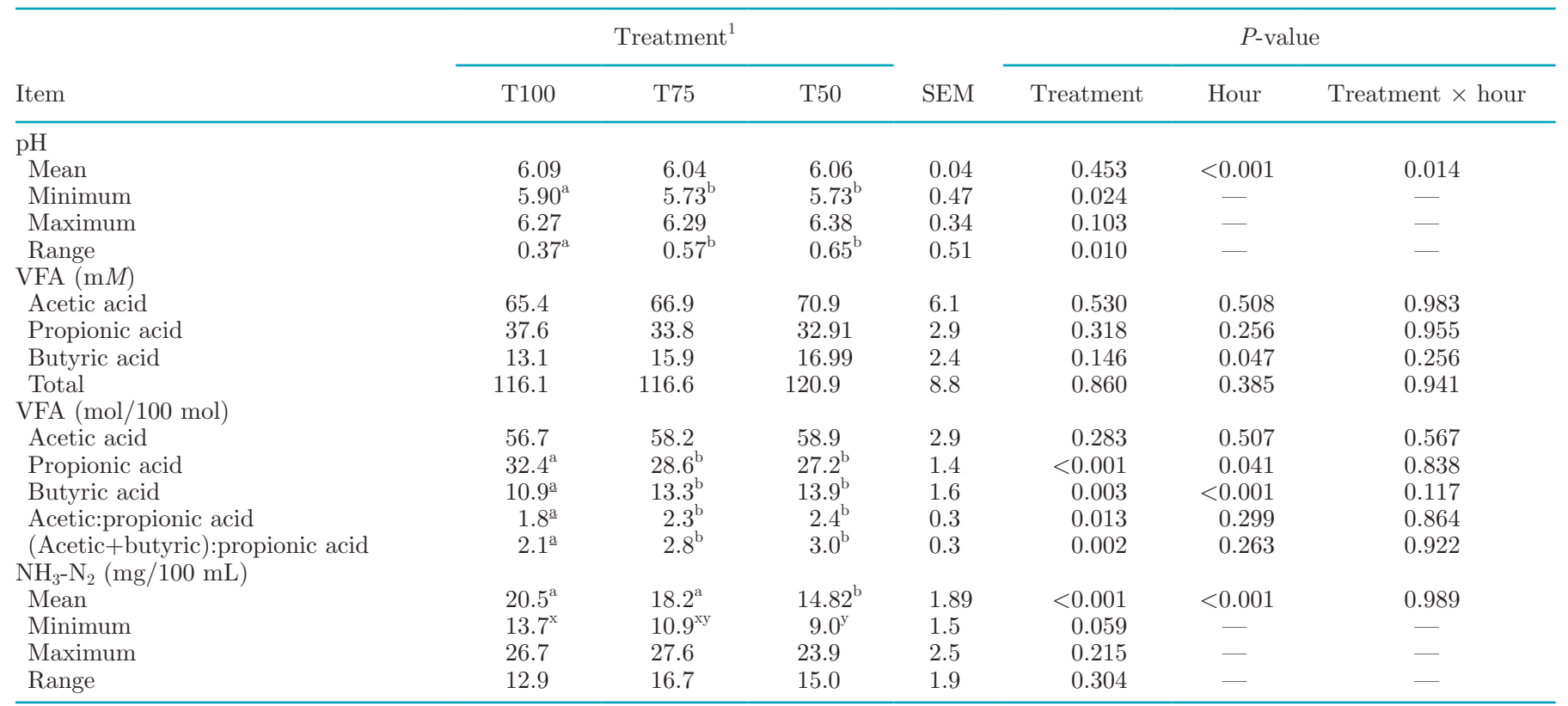

${ }^{\mathrm{a}, \mathrm{b}}$ Within a row, the means with different superscripts are different $(P \leq 0.05)$.

${ }^{\mathrm{x}, \mathrm{y}}$ Within a row, the means with different superscripts are different $(0.05<P<0.10)$.

${ }^{1} \mathrm{~T} 100=100 \%$ TMR; T75 $=75 \%$ TMR plus $25 \%$ fresh forage; T50 $=50 \%$ TMR plus $50 \%$ fresh forage.

ments in total PD excretion or in duodenal FMN in cows fed a diet based on TMR, combining TMR with FF, or FF supplemented with concentrates. It should be noted that Bargo et al. (2002b) estimated this trait using the allantoin-to-creatinine ratio, and they partially attributed the absence of a treatment effect to a lack of sensitivity of this technique. Although the higher duodenal FMN in T100 and T75 would suggest that greater efficiencies of $\mathrm{N}$ utilization to synthesize microbial $\mathrm{N}$ could be achieved when utilizing a TMR diet rather than a high-quality FF or a combination of both, no differences among treatments were observed for this variable. This result agrees with Mendoza et al. (2016b) in dairy cows and might be explained by the higher $\mathrm{N}$ intake achieved in the treatments with a higher TMR allocation.

\section{Milk Production and Composition}

Milk yield for cows in T100 and T75 was $8.5 \%$ higher compared with cows in T50 (Table 6), reflecting a higher nutrient intake. Several authors observed that milk production based on pasture diets might restrict the productive potential of the animals, mostly because of the low DMI achieved leading to a low energy intake (Kolver and Muller, 1998; Mendoza et al., 2016a). However, when no differences in DMI and nutrient intake are observed between cows fed with TMR alone or with $\mathrm{FF}$, no differences are observed in milk produc- tion (Vibart et al., 2008; Mendoza et al., 2016a). Milk composition was not affected by the treatments, but the solids yield followed the trends observed for milk production (Table 6). This is consistent with the intake of the different precursors of milk components, as well as the distinct ruminal VFA profile observed in the different treatments, a result that is coincident with the observations made by Bargo et al. (2002b) and Mendoza et al. (2016a). Contrary to the reports of several authors (Bargo et al., 2002b; Vibart et al., 2008), in our experiment MUN was lower in T50 despite the greater proportion of $\mathrm{FF}$ intake in the diet; however, the lower $\mathrm{N}$ intake in that treatment was consistent with previous works (Mendoza et al., 2016a).

The milk from cows in T50 had an $8 \%$ greater UFA than that from cows in T100 (Table 7), mainly due to a higher content of MUFA. This result is consistent with the reports by other authors (Bargo et al., 2006; Mendoza et al., 2016a), who observed that the inclusion of FF in the diet increased the milk UFA content. Similarly, cows in T50 had a greater amount of preformed fatty acids (Table 7) compared with cows in T100, which might be partially explained by an increased utilization of ingested fatty acids for milk fat synthesis (Palmquist et al., 1993) and agrees with results reported by Bargo et al. (2006) and Morales-Almaráz et al. (2010). Linolenic and vaccenic acid concentrations were higher for cows fed T50 than those fed T75, followed by those fed T100 (Table 6). In the case of rumenic acid, 

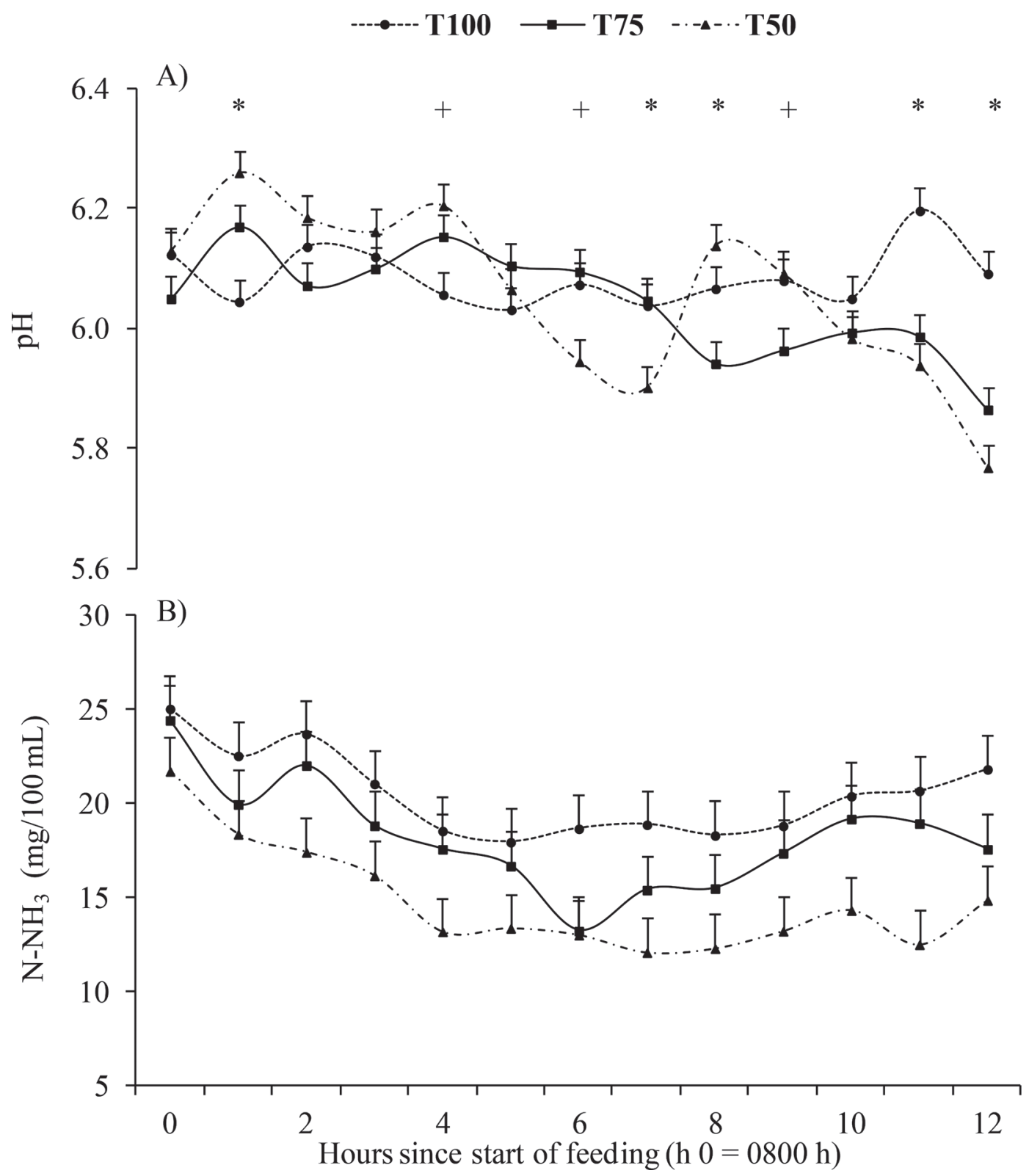

Figure 1. Ruminal pH (A) and ammonia-N concentrations $\left(\mathrm{NH}_{3}-\mathrm{N} ; \mathrm{B}\right)$ of dairy cows fed different proportions of TMR and fresh forage. Asterisks $(*)$ or crosses $(+)$ at each hour indicate at least 1 difference among the treatments, $P \leq 0.05$ or $0.05<P \leq 0.10$, respectively. T100 $=$ 100\% TMR; T75 = 75\% TMR plus 25\% fresh forage; T50 = 50\% TMR plus 50\% fresh forage. Error bars represent SEM.

cows in T50 produced milk with a higher concentration than cows in T100, and we noted a tendency for cows in T75 to produce milk with a higher concentration of rumenic acid than cows in T100 $(P=0.09)$. This result agrees with reports by other authors (Bargo et al., 2006; Mendoza et al., 2016a), who observed that, as FF replaced the TMR in the diet of dairy cows, the vaccenic and rumenic acid content increased in milk fat due to an increased linolenic acid intake, which is the major FA present in FF (Chilliard et al., 2002).
A higher content of rumenic and vaccenic acid for cows in T50 compared with cows in T100 and T75 suggests that the milk of these cows could have healthier characteristics for the consumers, as rumenic acid has nutraceutical properties, among which anticarcinogenic properties are prominent (Elgersma et al., 2006). In addition, a higher n-3 fatty acid intake and a diet with a balanced n-6:n-3 fatty acid ratio would benefit consumer health (Simopoulos, 2008); it has been recommended that diets should have an n-6:n-3 ratio lower than 5 
Table 5. Microbial N flow in dairy cows fed different proportions of TMR and fresh forage

\begin{tabular}{|c|c|c|c|c|c|}
\hline Item & \multicolumn{3}{|c|}{ Treatment $^{1}$} & SEM & $P$-value \\
\hline Creatinine $(\mathrm{m} M)$ & 8.4 & 8.8 & 9.0 & 0.46 & 0.503 \\
\hline Uric acid $(\mathrm{m} M)$ & 2.1 & 2.3 & 2.2 & 0.18 & 0.383 \\
\hline $\mathrm{PD}^{2}(\mathrm{~m} M)$ & 24.2 & 23.4 & 21.6 & 1.13 & 0.166 \\
\hline PD:creatinine & $2.9^{\mathrm{a}}$ & $2.7^{\mathrm{a}}$ & $2.4^{\mathrm{b}}$ & 0.09 & 0.009 \\
\hline Efficiency of $\mathrm{N}$ use for microbial $\mathrm{N}$ synthesis (\%) & 40.0 & 38.9 & 38.5 & 2.18 & 0.872 \\
\hline
\end{tabular}

${ }^{\mathrm{a}, \mathrm{b}}$ Within a row, the means with different superscripts are different $(P \leq 0.05)$.

${ }^{1} \mathrm{~T} 100=100 \%$ TMR; T75 $=75 \%$ TMR plus $25 \%$ fresh forage; T50 $=50 \%$ TMR plus $50 \%$ fresh forage.

${ }^{2} \mathrm{PD}=$ purine derivatives.

(AFSSA, 2001). In our experiment, milk fat from cows in $\mathrm{T} 50$ and $\mathrm{T} 75$ had a lower n-6:n-3 fatty acid ratio than that of cows in $\mathrm{T} 100$, and in both cases the ratio was below 5 . Milk fatty acid profile for cows in T50 exhibited a lower atherogenicity index than T100, which, in addition to the previously mentioned characteristics, suggests that the inclusion of FF in the diet of dairy cows might confer desirable traits to milk as food for consumers from a health point of view.

\section{CONCLUSIONS}

In our experiment, inclusion of up to $29 \%$ high-quality FF in the diet of cows fed TMR maintained similar levels of DMI and DM digestibility, as well as milk yield, compared with cows fed only TMR. However, a $47 \%$ inclusion of $\mathrm{FF}$ in the diet reduced both DMI and milk yield, although the concentrations of vaccenic, rumenic, and linolenic acids in milk fat were increased, which would result in a healthier food for consumers.
Even though these results are auspicious, it is necessary to generate more information to be able to determine if these findings can be maintained when these diets are applied to fresh cows, or to cows with greater productive potential, or when including another type of FF.

\section{ACKNOWLEDGMENTS}

The authors thank E. de Torres, Director of the Experimental Station of the Veterinary Faculty (San José, Uruguay), E. Aloy, M. Bazzano, Y. Borges, M. Burutarán, M. Calvo, I. Cruz, I. Fornio, P. Otegui, V. Oyarvide, and L. Rumia (veterinary students, Facultad de Veterinaria, San José, Uruguay) for help with animal care and M. Constantin, M. Calvo, and D. Hirigoyen (Laboratorio Agroindustrial Cooperativo Colaveco, Nueva Helvecia, Uruguay) for performing the fatty acid analysis. Nicolle Pomiés thanks Agencia Nacional de Investigación e Innovación (Montevideo, Uruguay; BE_POS_2011_1_3315) for the scholarship.

Table 6. Milk yield and composition of dairy cows fed different proportions of TMR and fresh forage

\begin{tabular}{|c|c|c|c|c|c|}
\hline \multirow{2}{*}{$\begin{array}{l}\text { Item }(\mathrm{kg} / \mathrm{d}, \\
\text { unless noted) }\end{array}$} & \multicolumn{3}{|c|}{ Treatment $^{1}$} & \multirow[b]{2}{*}{ SEM } & \multirow[b]{2}{*}{$P$-value } \\
\hline & T100 & T75 & $\mathrm{T} 50$ & & \\
\hline Milk & $31.0^{\mathrm{a}}$ & $30.0^{\mathrm{a}}$ & $27.9^{\mathrm{b}}$ & 1.02 & $<0.001$ \\
\hline $3.5 \% \mathrm{FCM}$ & $33.9^{\mathrm{a}}$ & $33.0^{\mathrm{a}}$ & $30.3^{\mathrm{b}}$ & 1.43 & $<0.001$ \\
\hline Fat & $1.26^{\mathrm{a}}$ & $1.24^{\mathrm{a}}$ & $1.13^{\mathrm{b}}$ & 0.06 & $<0.001$ \\
\hline Fat (\%) & 4.11 & 4.14 & 4.06 & 0.14 & 0.746 \\
\hline Protein & $1.04^{\mathrm{a}}$ & $1.02^{\mathrm{a}}$ & $0.94^{\mathrm{b}}$ & 0.04 & $<0.001$ \\
\hline Protein (\%) & 3.37 & 3.40 & 3.39 & 0.08 & 0.620 \\
\hline Lactose & $1.46^{\mathrm{a}}$ & $1.43^{\mathrm{a}}$ & $1.32^{\mathrm{b}}$ & 0.05 & $<0.001$ \\
\hline Lactose (\%) & $4.75^{\mathrm{xy}}$ & $4.78^{y}$ & $4.74^{\mathrm{x}}$ & 0.02 & 0.070 \\
\hline MUN (mg/dL) & $24.7^{\mathrm{a}}$ & $22.8^{\mathrm{a}}$ & $20.5^{\mathrm{b}}$ & 1.83 & $<0.001$ \\
\hline Total casein & $0.76^{\mathrm{a}}$ & $0.73^{\mathrm{a}}$ & $0.68^{\mathrm{b}}$ & 0.04 & $<0.001$ \\
\hline Total casein (\%) & 2.44 & 2.49 & 2.47 & 0.08 & 0.394 \\
\hline Casein:protein ratio & 0.73 & 0.72 & 0.72 & 0.01 & 0.684 \\
\hline
\end{tabular}


Table 7. Milk fatty acid (FA) profile and components of dairy cows fed different proportions of TMR and fresh forage

\begin{tabular}{|c|c|c|c|c|c|}
\hline \multirow{2}{*}{$\begin{array}{l}\text { FA content } \\
(\mathrm{g} / 100 \mathrm{~g} \text { of total FA) }\end{array}$} & \multicolumn{3}{|c|}{ Treatment $^{1}$} & \multirow[b]{2}{*}{ SEM } & \multirow[b]{2}{*}{$P$-value } \\
\hline & $\mathrm{T} 100$ & $\mathrm{~T} 75$ & $\mathrm{~T} 50$ & & \\
\hline \multicolumn{6}{|l|}{ Selected individual FA } \\
\hline $4: 0$ & 2.16 & 2.15 & 1.98 & 0.14 & 0.577 \\
\hline $6: 0$ & 2.17 & 2.16 & 1.98 & 0.12 & 0.368 \\
\hline $8: 0$ & 1.71 & 1.71 & 1.55 & 0.10 & 0.131 \\
\hline 10:0 & 4.11 & 4.10 & 3.82 & 0.31 & 0.249 \\
\hline $12: 0$ & $4.98^{\mathrm{x}}$ & $4.87^{\mathrm{xy}}$ & $4.50^{\mathrm{y}}$ & 0.33 & 0.052 \\
\hline $14: 0$ & 13.21 & 13.28 & 13.00 & 0.49 & 0.472 \\
\hline $14: 1$ cis- 9 & 1.51 & 1.46 & 1.54 & 0.11 & 0.666 \\
\hline $15: 0$ & 1.38 & 1.35 & 1.40 & 0.10 & 0.741 \\
\hline $16: 0$ & $36.10^{\mathrm{a}}$ & $34.27^{\mathrm{b}}$ & $34.43^{\mathrm{b}}$ & 0.73 & $<0.001$ \\
\hline $16: 1$ cis -9 & 2.39 & 2.33 & 2.44 & 0.22 & 0.572 \\
\hline $18: 0$ & $7.98^{\mathrm{x}}$ & $8.73^{\mathrm{xy}}$ & $8.77^{\mathrm{y}}$ & 0.54 & 0.072 \\
\hline $18: 1$ trans -9 & 0.26 & 0.28 & 0.30 & 0.02 & 0.282 \\
\hline $18: 1$ cis $-9^{2}$ & 16.88 & 17.64 & 18.03 & 1.00 & 0.199 \\
\hline $18: 1$ trans $-11^{3}$ & $0.97^{\mathrm{a}}$ & $1.44^{\mathrm{b}}$ & $1.88^{\mathrm{c}}$ & 0.16 & $<0.001$ \\
\hline $18: 2$ cis- 9, cis- 12 & $2.11^{\mathrm{a}}$ & $1.76^{\mathrm{b}}$ & $1.52^{\mathrm{c}}$ & 0.11 & $<0.001$ \\
\hline $18: 2$ cis- 9, trans $-11^{4}$ & $0.40^{\mathrm{a}}$ & $0.60^{\mathrm{a}}$ & $0.88^{\mathrm{b}}$ & 0.10 & $<0.001$ \\
\hline $18: 3$ cis- 9, cis- 12, cis $-15^{5}$ & $0.25^{\mathrm{a}}$ & $0.38^{\mathrm{b}}$ & $0.48^{\mathrm{c}}$ & 0.04 & $<0.001$ \\
\hline \multicolumn{6}{|l|}{ Summation by origin } \\
\hline De novo $(4: 0-15: 0)$ & 31.96 & 31.72 & 30.39 & 1.38 & 0.195 \\
\hline Mixed origin $(16: 0+16: 1)$ & $38.48^{\mathrm{a}}$ & $36.60^{\mathrm{b}}$ & $36.87^{\mathrm{b}}$ & 0.84 & 0.002 \\
\hline Preformed $(>17: 0)$ & $29.55^{\mathrm{a}}$ & $31.68^{\mathrm{ab}}$ & $32.74^{\mathrm{b}}$ & 1.36 & 0.031 \\
\hline \multicolumn{6}{|l|}{ Summation by saturation } \\
\hline SFA & $74.42^{\mathrm{a}}$ & $73.42^{\mathrm{ab}}$ & $72.21^{\mathrm{b}}$ & 1.23 & 0.049 \\
\hline MUFA & $22.82^{\mathrm{a}}$ & $23.84^{\mathrm{ab}}$ & $24.91^{\mathrm{b}}$ & 1.14 & 0.031 \\
\hline PUFA & 2.75 & 2.74 & 2.88 & 1.17 & 0.617 \\
\hline UFA & $25.58^{\mathrm{a}}$ & $26.58^{\mathrm{ab}}$ & $27.79^{\mathrm{b}}$ & 1.23 & 0.049 \\
\hline Saturated:unsaturated ratio & $2.93^{\mathrm{x}}$ & $2.80^{\mathrm{xy}}$ & $2.63^{\mathrm{y}}$ & 0.17 & 0.052 \\
\hline n-6:n-3 ratio & $9.15^{\mathrm{a}}$ & $4.80^{\mathrm{b}}$ & $3.31^{\mathrm{c}}$ & 0.45 & $<0.001$ \\
\hline$\Delta^{9}$-desaturase index ${ }^{6}$ & 0.27 & 0.28 & 0.28 & 0.11 & 0.132 \\
\hline Atherogenicity index ${ }^{7}$ & $3.73^{\mathrm{a}}$ & $3.52^{\mathrm{ab}}$ & $3.31^{\mathrm{b}}$ & 0.24 & 0.038 \\
\hline \multicolumn{6}{|c|}{${ }^{\mathrm{a}-\mathrm{C}}$ Within a row, the means with different superscripts are different $(P<0.05)$. } \\
\hline \\
\hline \multirow{2}{*}{\multicolumn{6}{|c|}{$\begin{array}{l}{ }^{1} \mathrm{~T} 100=100 \% \mathrm{TMR} ; \mathrm{T} 75=75 \% \text { TMR plus } 25 \% \text { fresh forage; T50 }=50 \% \text { TMR plus } 50 \% \text { fresh forage. } \\
{ }^{2} \text { Oleic acid. }\end{array}$}} \\
\hline & & & & & \\
\hline \multicolumn{6}{|c|}{${ }^{3}$ Vaccenic acid. } \\
\hline \multicolumn{6}{|l|}{${ }^{4}$ Rumenic acid. } \\
\hline \multicolumn{6}{|c|}{${ }^{5}$ Linolenic acid. } \\
\hline \multicolumn{6}{|c|}{$\begin{array}{l}{ }^{6} \text { Calculated as }(14: 1 \text { cis- } 9+16: 1 \text { cis }-9+18: 1 \text { cis }-9+18: 2 \text { cis- } 9, \text { trans }-11) /(14: 0+16: 0+18: 0+18: 1 \text { trans }-11 \\
+14: 1 \text { cis- } 9+16: 1 \text { cis }-9+18: 1 \text { cis }-9+18: 2 \text { cis }-9, \text { trans }-11) .\end{array}$} \\
\hline${ }^{7}$ Calculated as $(12: 0+4 \times 1$ & MUFA + & & & & \\
\hline
\end{tabular}

Special thanks to Kenneth Kalscheur from the USDAARS (Washington, DC) for his invaluable collaboration in improving the text of this manuscript.

\section{REFERENCES}

Adams, R. F., R. L. Jones, and P. L. Conway. 1984. High-performance liquid chromatography of microbial acid metabolites. J. Chromatogr. 336:125-137.

AFSSA. 2001. The Omega 3 Fatty Acids and the Cardiovascular System: Nutritional Benefits and Claims. Agence Française de Sécurité Sanitaire des Aliments (AFSSA), Maisons-Alfort, France.

Aguerre, M., C. Cajarville, G. V. Kozloski, and J. L. Repetto. 2013. Intake and digestive responses by ruminants fed fresh temperate pasture supplemented with increased levels of sorghum grain: A comparison between cattle and sheep. Anim. Feed Sci. Technol. 186:12-19.
AOAC. 1990. Official Methods of Analysis. 15th ed. Association of Official Analytical Chemists, Arlington, VA.

Balcells, J., J. A. M. Guada, and M. Peiró. 1992. Simultaneous determination of 539 allantoin and oxypurines in biological fluids by high-performance liquid 540 chromatography. J. Chromatogr. 575:153-157.

Bargo, F., J. E. Delahoy, G. F. Schroeder, L. H. Baumgardc, and L. D. Muller. 2006. Supplementing total mixed rations with pasture increase the content of conjugated linoleic acid in milk. Anim. Feed Sci. Technol. 131:226-240.

Bargo, F., L. D. Muller, J. E. Delahoy, and T. W. Cassidy. 2002b. Performance of high producing dairy cows with three different feeding systems combining pasture and total mixed rations. J. Dairy Sci. 85:2948-2963.

Bargo, F., L. D. Muller, E. S. Kolver, J. E. Delahoy, and T. W. Cassidy. 2002a. Milk response to concentrate supplementation of high producing dairy cow grazing at two pasture allowances. J. Dairy Sci. 85:1777-1792. 
Bargo, F., L. D. Muller, G. A. Varga, J. E. Delahoy, and T. W. Cassidy. 2002c. Ruminal digestion and fermentation of high-producing dairy cows with three different feeding systems combining pasture and total mixed rations. J. Dairy Sci. 85:2964-2973.

Broderick, G. A., M. J. Stevenson, and R. A. Patton. 2009. Effect of dietary protein concentration and degradability on response to rumen-protected methionine in lactating dairy cows. J. Dairy Sci. 92:2719-2728.

Calsamiglia, S., P. M. Cardozo, A. Ferret, and A. Bach. 2008. Changes in rumen microbial fermentation are due to a combined effect of type of diet and pH. J. Anim. Sci. 86:702-711.

Castillo, A. R., E. Kebreab, D. E. Beever, and J. France. 2000. A review of efficiency of nitrogen utilisation in lactating dairy cows and its relationship with environmental pollution. J. Anim. Feed Sci. 9:1-32.

Chaudry, A. S. 2008. Forage based animal production systems and sustainability, an invited keynote. Rev. Bras. Zootec. 37:78-84.

Chen, X. B., and M. J. Gomes. 1992. Estimation of Microbial Protein Supply to Sheep and Cattle Based on Urinary Excretion of Purine Derivatives-An Overview of the Technical Details. International Feed Resources Unit Rowett Research Institute, Bucksburn Aberdeen, United Kingdom.

Chilliard, Y., A. Ferlay, J. Loor, and B. Martin. 2002. Trans and conjugated fatty acids in milk from cows and goats consuming pasture or receiving vegetable oils seed. Ital. J. Anim. Sci. 1:243-254.

Clark, J. H., T. H. Klusmeyer, and M. R. Cameron. 1992. Microbial protein synthesis and flows of nitrogen fractions to the duodenum of dairy cows. J. Dairy Sci. 75:2304-2323.

Colmenero, J. J., and G. A. Broderick. 2006. Effect of dietary crude protein concentration on milk production and nitrogen utilization in lactating dairy cows. J. Dairy Sci. 89:1704-1712.

Elgersma, A., S. Tamminga, and G. Ellen. 2006. Review: Modifying milk composition through forage. Anim. Feed Sci. Technol. 131:207-225

Feng, S., A. L. Lock, and P. C. Garnsworthy. 2004. Technical note: A rapid lipid separation method for determining fatty acid composition of milk. J. Dairy Sci. 87:3785-3788.

France, J., and J. Dijkstra. 2005. Volatile fatty acid production. Pages 157-175 in Quantitative Aspects of Ruminant Digestion and Metabolism., 2nd ed. J. Dijkstra, J. Forbes, and J. France, ed. CAB International, Wallingford, United Kingdom.

Huhtanen, P., K. Kaustell, and S. Jaakkola. 1994. The use of internal markers to predict total digestibility and duodenal flow of nutrients in cattle given six different diets. Anim. Feed Sci. Technol. $48: 211-227$.

Kelsey, J. A., B. A. Corl, R. J. Collier, and D. E. Bauman. 2003. The effect of breed, parity, and stage of lactation on conjugated linoleic acid (CLA) in milk fat from dairy cows. J. Dairy Sci. $86: 2588-2597$.

Khalili, H., and A. Sairanen. 2000. Effect of concentrate type on rumen fermentation and milk production of cows at pasture. Anim. Feed Sci. Technol. 84:199-212.

Kolver, E. S. 2003. Nutritional limitations to increased production on pasture-based systems. Proc. Nutr. Soc. 62:291-300.

Kolver, E. S., and L. D. Muller. 1998. Performance and nutrient intake of high producing Holstein cows consuming pasture or a total mixed ration. J. Dairy Sci. 81:1403-1411.
Licitra, G., T. M. Hernandez, and P. J. Van Soest. 1996. Standardization of procedures for nitrogen fractionation of ruminant feeds. Anim. Feed Sci. Technol. 57:347-358.

Littell, R. C., P. R. Henry, and C. B. Ammerman. 1998. Statistical analysis of repeated measures data using SAS procedures. J. Anim. Sci. 76:1216-1231.

Mendoza, A., C. Cajarville, and J. L. Repetto. 2016a. Short communication: Intake, milk production, and milk fatty acid profile of dairy cows fed diets combining fresh forage with a total mixed ration. J. Dairy Sci. 99:1938-1944.

Mendoza, A., C. Cajarville, and J. L. Repetto. 2016b. Digestive response of dairy cows fed diets combining fresh forage with a total mixed ration. J. Dairy Sci. 99:8779-8789.

Mendoza, A., C. Cajarville, and J. L. Repetto. 2018. Behaviour of cows fed a total mixed ration with different access time to fresh forage. N. Z. J. Agric. Res. 61:102-108.

Morales-Almaráz, E., A. Soldado, A. Gonzalez, A. Martínez-Fernández, I. Domínguez-Vara, B. de la Roza-Delgado, and F. Vicente. 2010. Improving the fatty acid profile of dairy cow milk by combining grazing with feeding of total mixed ration. J. Dairy Res. $77: 225-230$.

NRC. 2001. Nutrient Requirements of Dairy Cattle. 7th rev. ed. Natl. Acad. Press, Washington, DC.

Palmquist, D. L., A. D. Beaulieu, and D. M. Barbano. 1993. ADSA foundation symposium: Milk fat synthesis and modification. Feed and animal factors influencing milk fat composition. J. Dairy Sci. $76: 1753-1771$.

Reynal, S. M., and G. A. Broderick. 2005. Effect of dietary level of rumen-degraded protein on production and nitrogen metabolism in lactating dairy cows. J. Dairy Sci. 88:4045-4064.

Simopoulos, A. P. 2008. The importance of the Omega-6/Omega-3 fatty acid ratio in cardiovascular disease and other chronic diseases. Exp. Biol. Med. (Maywood) 233:674-688.

Sniffen, C. J., J. D. O'Connor, P. J. Van Soest, D. G. Fox, and J. B. Russel. 1992. A net carbohydrate and protein system for evaluating cattle diets: II. Carbohydrate and protein availability. J. Anim. Sci. 70:3562-3577.

Tyrrell, H. F., and J. T. Reid. 1965. Prediction of the energy value of cow's milk. J. Dairy Sci. 48:1215-1223.

Ulbricht, T. L. V., and D. A. T. Southgate. 1991. Coronary heart disease: seven dietary factors. Lancet 338:985-992.

Valadares, R. F. D., G. A. Broderick, S. C. Valadares Filho, and M. K. Clayton. 1999. Effect of replacing alfalfa silage with high moisture corn on ruminal protein synthesis estimated from excretion of total purine derivatives. J. Dairy Sci. 82:2686-2696.

Van Soest, P. J. 1994. Nutritional Ecology of the Ruminant. 2nd ed. Cornell University Press, Ithaca, NY.

Van Soest, P. J., J. B. Robertson, and B. A. Lewis. 1991. Methods for dietary fiber, neutral detergent fiber, and nonstarch polysaccharides in relation to animal nutrition. J. Dairy Sci. 74:3583-3597.

Van Vuuren, A. M., C. J. van der Koelen, and J. Vroons de Bruin. 1986. Influence of level and composition of concentrate supplements on rumen fermentation patterns of grazing cows. Neth. J. Agric. Sci. 34:457-467.

Vibart, R. E., V. Fellner, J. C. Burns, J. B. Huntington, and J. T. Green Jr.. 2008. Performance of lactating dairy cows fed varying levels of total mixed ration and pasture. J. Dairy Res. 75:471-480. 